\title{
Iliac allograft used for sternal reconstruction after resection of a chondrosarcoma
}

\author{
J. A. Cara, A. F. Laclériga, and J. Cañadell \\ Department of Orthopaedic Surgery, University Clinic, Faculty of Medicine, University \\ of Navarre, Pamplona, Spain
}

\section{SUMMARY}

We report the case of a man, aged 48 years, with a primary chondrosarcoma of the sternum which was treated by radical resection and reconstruction with an iliac allograft and musculocutaneous flaps. No complications were seen at follow up after two years.

\section{RÉSUMÉ}

Nous présentons le cas d'un homme de 48 ans, porteur d'un chondrosarcome primaire du sternum. Il a subi une résection radicale suivie de reconstruction par allogreffe iliaque. Deux ans plus tard aucune complication n'a été observée. On discute la valeur de cette nouvelle méthode de reconstruction à l'aide d'allogreffes pour ce type de tumeurs, parrapport aux procédés thérapeutiques classiques.

Reprint requests to: J. A. Cara

Dpt. of Orthopaedic Surgery.

Clínica Universitaria de Navarra.

Aptdo 192, E-31080 Pamplona, Spain

\section{INTRODUCTION}

Tumours of the ribs, scapula, sternum and clavicle make up 5\% of all bone tumours [11], and the sternum is affected in $10 \%$ of there $[19,20]$. The most frequently occurring tumour is a chondrosarcoma which represents $70 \%$ of all the primary tumours in this region [22]. Other tumours have also been described (Table 1).

The typical presentation is a painless lump on the anterior chest wall in an elderly individual. Radiographs show a cartilaginous neoplasm with a typically mineralised cartilage matrix and a pattern of stippled, flocculent or curvilinear calcification [2]. Further investigation includes a CT scan, magnetic resonance imaging and radio-isotope scanning [18].

Wide radical resection is the main treatment. In some cases, embolisation of the principal artery can reduce the tumour mass and make the resection easier [24]. Several 
procedures have been proposed for reconstruction of the bony defect (Table 2), but there have been no reports of the use of bone allografts. Closure of the anterior wall of the chest may be difficult and musculocutaneous flaps can be used. Radiotherapy is an option. Skin necrosis and the failure of pedicular flaps are the most frequent complications.

\section{CASE REPORT}

A man, aged 48 years, presented with a large painless mass in the anterior chest wall which he had noticed 18 months previously, but had only become painful recently.

A radiograph of the chest showed cortical thickening of the sternum. Magnetic resonance imaging (MRI) demonstrated a large lobulated mass in the middle of the sternum containing some areas of soft tissue calcification; there appearances suggested a malignant tumour (Fig. 1).

At operation, an en bloc resection of the tumour (partial sternectomy) was carried out and an iliac graft used for reconstruction (Fig. 2). The graft was fixed with cerclage wires and covered with musculocutaneous flaps containing rectus abdominis.

A CT scan 2 years later showed an acceptable appearance (Fig. 3). The patient had normal respiratory function and was free from disease.

\section{DISCUSSION}

Sternal tumours are rare, although chondrosarcoma is the most common primary tumour of sternum or ribs. The radiological appearance may lead to confusion with pulmonary or mediastinal tumours.

Surgical treatment has three priorities, complete or wide resection, reconstruction of the chest wall to allow adequate spontaneous ventilation, and cosmetically acceptable skin coverage. Operation is justified when the tumour is primary, and in solitary metastases when the primary is curable. En bloc resection must be based on pre-operative CT or MRI imaging to determine the extent of the tumour and the margins of the tumour resection during surgery.

Reconstruction of the chest wall can be difficult and if the chest remains unstable the immediate prognosis can be jeopardised because of paradoxical respiration and, in the long term, because of the functional and cosmetic impairment due to progressive impaction of the unstable segment of the chest wall.

A bone allograft is a biological material which allows consolidation, but most authors have used nonbiological material $[10,17]$ or autogenous rib grafts [17].

In our case, bony stability was achieved by union between host and allograft so that the patient became normally active. The graft stabilises the shoulder girdle and protects the mediastinum. The use of muscle flaps is important because they help to vascularise the graft. Rectus abdominis is satisfactory, easy to use and gives good results [17]. 
A bone allograft after resection of sternal tumours is a better solution than using nonbiological material.

\section{REFERENCES}

1. Angilello A, Artale S, Santagati U (1969). Su un raro caso di tumore benigno dello sterno. Minerva Chir 24: 388-392

2. Aoki J, Moser RP, Kransdorf MJ (1989) Chondrosarcoma of the sternum: CT features. J Comput Assist Tomogr 13: 806-810

3. Baffi RR, Didolkar MS, Bakamjiam V (1977) Reconstruction of sternal and abdominal wall defects in case of desmoid tumor. J Thorac Cardiovasc Surg 74: 105-108

4. Boker SM, Cullen GM, Swank M, Just JF (1990) Case report 593: hemangioma of sternum. Skeletal Radiol 19: 77-78

5. Borrelly J, Grosdidier G, Boileau S, Wack B (1990) Plastic surgery of the thoracic wall (malformations and tumors) using a sliding splint-stapler. Ann Chir Plast Esthet 35: 57-61

6. Chiau JH, Chamg TK, Hwang B, Tiu CM (1990) Eosinophilic granuloma of sternum. Report of one case. Acta Pediatr Sin 31: 35-39

7. Franken EA Jr, Smith JA, Smith WL (1977) Tumors of the chest wall in infants and children. Pediatr Radiol 6: 13-18

8. Gabbay S, Bennett RD, Amato J, Cherny EJ (1989) Controversies in management of sternal tumors. Ann Thorac Surg 48: 428-431

9. Hatlinghus S, Rode L, Chistensen I, Vaage S (1986) Sarcoma following irradiation for breast cancer. Report of three unusual cases including one malignant mesenchymoma of bone. Acta Radiol Oncol 25: 239-242

10. Herrersos J, Glock I, Echave V, Tejeira J (1982). Surgical treatment of sternal tumors. Rey Med Univ Navarra 26: 241-244

11. Knysh IT (1980) Diagnostic and treatment principies in primary tumors of the flat bones. Vopr Onkol 26: 37-40

12. Kruse C, Sander P (1987) Amyloid tumor of bone. Zentralbl Allg Pathol 133: 3-6

13. Lopez R, Didolkar MS, Karakousis C, Baffi R, Bakamjian V (1979) Problems in resection of chest wall sarcomas. Am Surg 45: 471-477

14. McKenna RJ, Mountain CF, McMurtrey MJ, Larson D, Stiles QR (1988) Current techniques for chest wall reconstruction; expanded possibilities for treatment. Ann Thorac Surg 46: 508-512

15. Merkle NM, Isele G, Vogt-Moykopf I (1987) Surgical therapy of primary chest wall tumors; experiences with 98 patients. Langenbecks Arch Chir 372: 785-789

16. Merkow RL, Lane JM (1990) Paget's disease of the bone. Orthop Clin N Am 21: 171-189

17. Pairolero PC, Arnold PG (1986) Thoracic wall defects; surgical management of 205 consecutive patients. Mayo Clin Proc 61: 557-563

18. Prauer HW, Mack D (1983) Special diagnostic and therapeutic problems with primary bone tumors of the chest wall. Langenbecks. Arch Chir 359: 143-152

19. Reck T, Bartsch M, Kockerling F, Hohenberger W (1987) Primary and secondary wall turnors diagnosis, therapy and results. Langenbecks Arch Chir 372: 791-795

20. Sabanathan S, Salama FD, Morgan WE, Harvey JA (1985) Primary chest wall tumors. Ann Thorac Surg 39: 4-15 
21. Sudaram M, Martin SA, Johnson FE, Wolverson MK (1982) Case report 198. Giant cell tumor of manubrium. Skeletal Radiol 8: 225-227

22. Trapeznikov NN, Cheremushkin EA, Lukianchenko AB, Khmelev ON (1990). The diagnosis and treatment of primary malignant tumors of the sternum. Vopr Onkol 36: 927-934

23. Tschantz P, Milliet A, Groebli Y, Khatchatourian G (1991) Reconstrutive methods of the anterolateral thoracic wall after extensive surgery of invasive tumors. Hely Chir Acta 58: 191-195

24. Tuengerthal S (1987) Conventional study in the diagnosis of primary and secondary chest wall tumors. Langenbecks Arch Chir 372: 769-777 


\begin{tabular}{|l|l|}
\hline \multicolumn{2}{|c|}{ Table 1. Reported cases of tumours in the sternum } \\
\hline Eosinophilic granuloma & (Chiau et al. 1990) \\
\hline Haemangioma & (Boker et al. 1990) \\
\hline Metastasis & (Herreros et al. 1982) \\
\hline Giant cell tumour & (Angilello et al. 1969; Sudaran et al. 1982) \\
\hline Postradiation sarcoma & (Hatlinghus et al. 1986) \\
\hline Plasmacytoma & $\begin{array}{l}\text { (Gabbay et al. 1990; Kruse and Sander 1987; Trapeznikov } \\
\text { et al. 1990) }\end{array}$ \\
\hline Ewing sarcoma & (Franken et al. 1977) \\
\hline Desmoid tumour & (Baffi et al. 1977) \\
\hline Osteosarcoma & (Trapeznikov et al. 1990) \\
\hline
\end{tabular}

Table 2. Materials used for the sternal reconstruction

\begin{tabular}{|l|l|}
\hline Marlex Mesh & $\begin{array}{l}\text { (Baffi et al. 1977; Lopez et al. 1979; Merkle et al. 1987; } \\
\text { McKenna et al. 1988) }\end{array}$ \\
\hline Methylmethacrylate & (Herreros et al. 1982) \\
\hline Rib autograph & (Pairolero and Arnold 1988) \\
\hline Sliding Splint-Stapler & (Borrelly et al. 1990) \\
\hline Bone cement & (Tschantz et al. 1991) \\
\hline
\end{tabular}




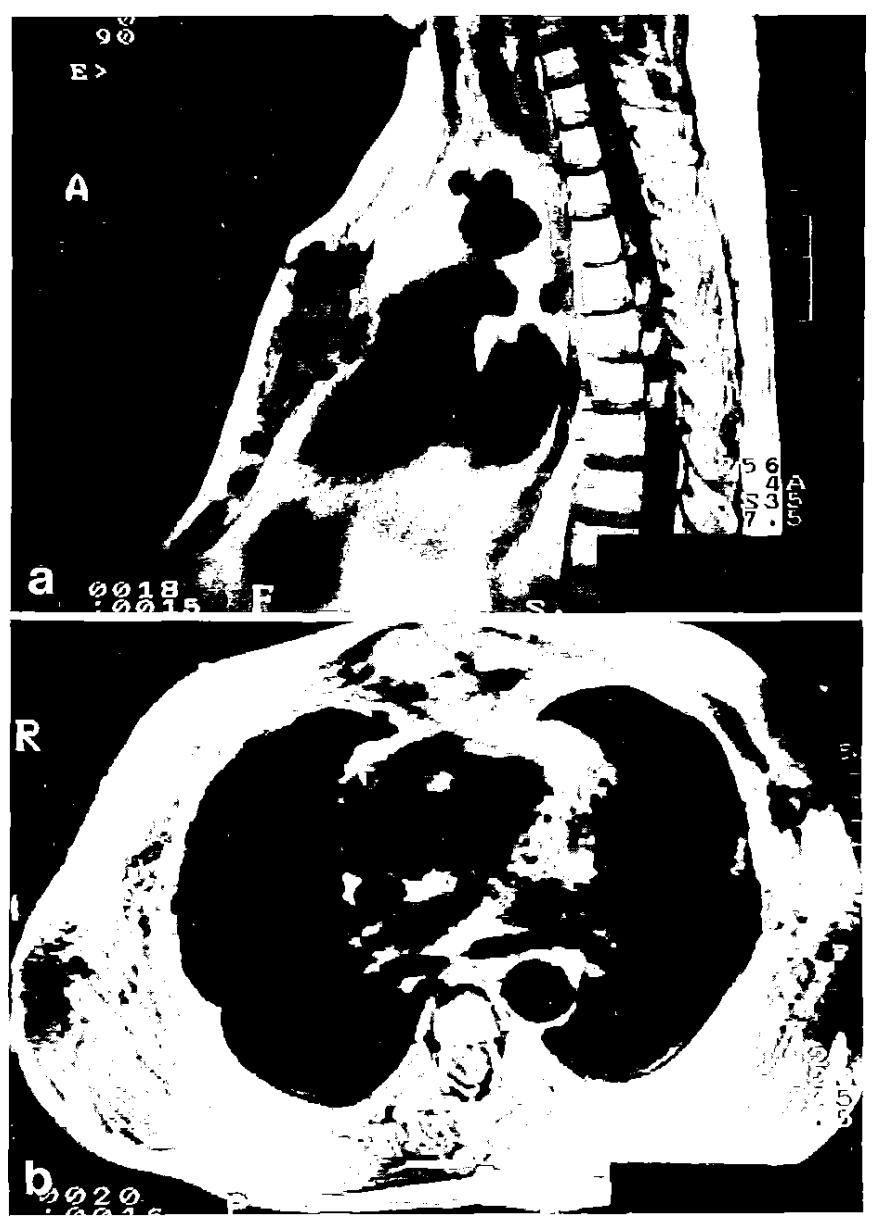

Figure 1 a, b. Pre-operative MRI imaging to show the mass in the sternum

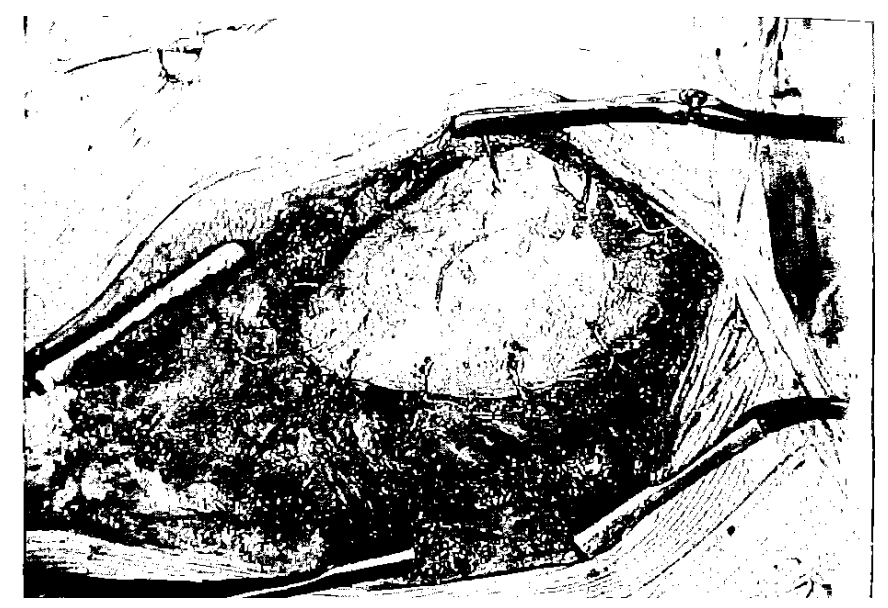

Figure 2. Photograph showing the allograft in position 


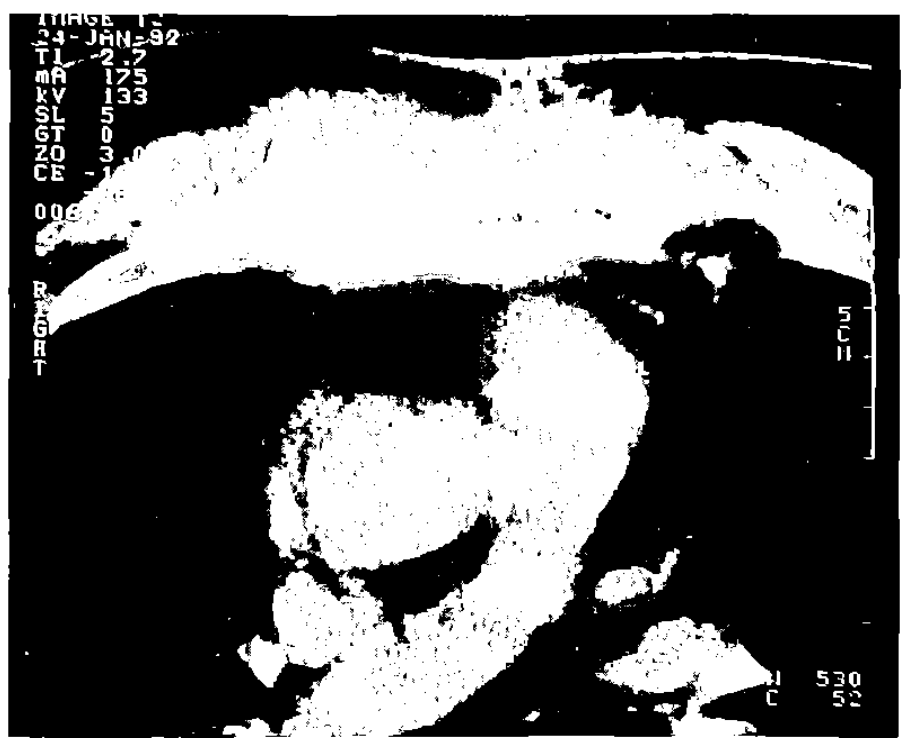

Figure 3. CT scan 2 years after operation showing an acceptable position 